\title{
Probabilistic approach to modeling lava flow inundation: a lava flow hazard assessment for a nuclear facility in Armenia
}

\author{
Laura J Connor ${ }^{1 *}$, Charles B Connor ${ }^{1}$, Khachatur Meliksetian² and Ivan Savov ${ }^{3}$
}

\begin{abstract}
Probabilistic modeling of lava flow hazard is a two-stage process. The first step is an estimation of the possible locations of future eruptive vents followed by an estimation of probable areas of inundation by lava flows issuing from these vents. We present a methodology using this two-stage approach to estimate lava flow hazard at a nuclear power plant site near Aragats, a Quaternary volcano in Armenia.
\end{abstract}

Keywords: lava flow simulation, modeling code, probabilistic hazard assessment, spatial density, Monte Carlo method, Armenia

\section{Background}

Volcanic hazard assessments are often conducted for specific sites, such as nuclear facilities, dams, ports and similar critical facilities that must be located in areas of very low geologic risk (Volentik et al 2009; Connor et al 2009). These hazard assessments consider the hazard and risk posed by specific volcanic phenomena, such as lava flows, tephra fallout, or pyroclastic density currents (IAEA 2011; Hill et al 2009). Although site hazards could be considered in terms of the cumulative effects of these various volcanic phenomena, a better approach is to assess the hazard and risk of each phenomenon separately, as they have varying characteristics and impacts. Here, we develop a methodology for site-specific hazard assessment for lava flows. Lava flows are considered to be beyond the design basis of nuclear facilities, meaning that the potential for the occurrence of lava flows above some level of acceptable likelihood would exclude the site from development of nuclear facilities because safe control or shutdown of the facility under circumstances of lava flow inundation cannot be assured (IAEA 2011).

This paper describes a computer model used to estimate the conditional probability that a lava flow will inundate a designated site area, given that an effusive eruption originates from a vent within the volcanic

\footnotetext{
* Correspondence: Iconnor@usf.edu

'University of South Florida, 4202 E. Fowler Ave, Tampa, FL 33620, USA Full list of author information is available at the end of the article
}

system of interest. There are two essential features of the analysis. First, the location of the lava flow source is sampled from a spatial density model of new, potentially eruptive vents. Second, the model simulates the effusion of lava from this vent based on field measurements of thicknesses and volumes of previously erupted lava flows within an area encompassing the site of interest. The simulated lava flows follow the topography, represented by a digital elevation model (DEM). Input data that are needed to develop a probability model include the spatial distribution of past eruptive vents, the distribution of past lava flows within an area surrounding the site, and measurable lava flow features including thickness, length, volume, and area, for previously erupted lava flows. Thus, the model depends on mappable features found in the site area. Given these input data, Monte Carlo simulations generate many possible vent locations and many possible lava flows, from which the conditional probability of site inundation by lava flow, given the opening of a new vent, is estimated. An example based on a nuclear power plant site in Armenia demonstrates the strengths of this type of analysis (Figure 1).

\section{Spatial density estimation}

Site-specific lava flow hazard assessments require that the hazard of lava inundation be estimated long before lava begins to erupt from any specific vent. In many eruptions, lavas erupt from newly formed vents, hence, 


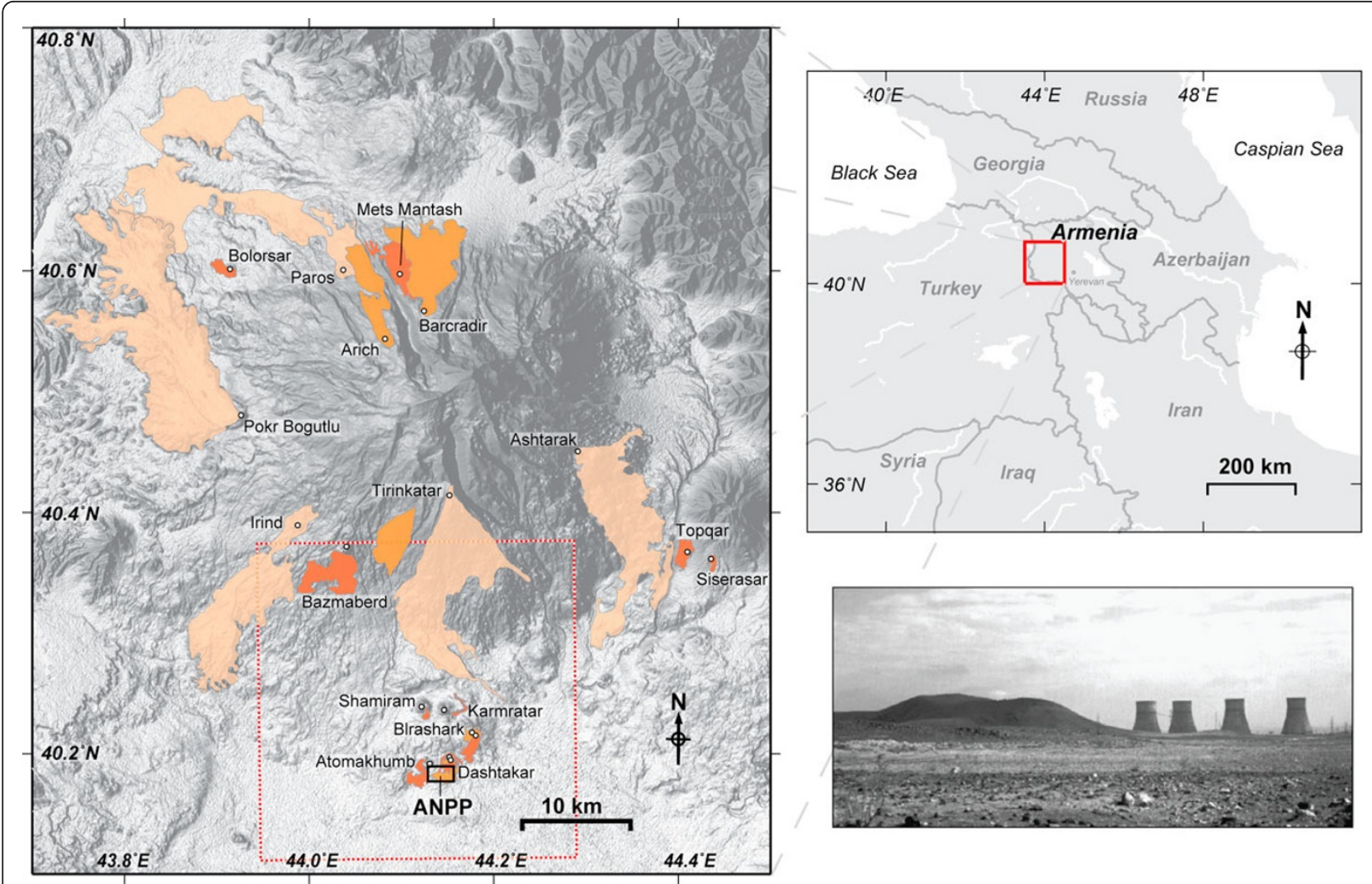

Figure 1 Location of study area in Armenia. The study area, outlined by a red box on the location map, is located in SW Armenia. The more detailed view shows the areal extent and location of effusion-limited (lighter colored) and volume-limited (darker colored) lava flows located around Aragats volcano. Details of each of these lava flows can be found in Table 1. The dashed red box identifies the boundaries of the lava flow simulation area. The Shamiram Plateau is an elevated region (within the central portion of the lava flow simulation area) comprising lava flows from Shamiram, Atomakhumb, Dashtakar, Blrashark, and Karmratar volcanoes. The ANPP site (black box) is located on the Shamiram Plateau. Photo shows the ANPP site and Atomakhumb volcano.

the potential spatial distribution of new vents must be estimated as part of the analysis. This is particularly important because the topography around volcanoes is often complex and characterized by steep slopes. Small variations in vent location may cause lava to flow in a completely different direction down the flanks of the volcano. Thus, probabilistic models of lava flow inundation are quite sensitive to models of vent location. Furthermore, many volcanic systems are distributed. Examples include monogenetic volcanic fields (e.g. the Michoacán-Guanajuato volcanic field, Mexico), distributed composite volcanoes which lack a central crater (e.g. Kirishima volcano, Japan), and volcanoes with significant flank activity (e.g. Mt. Etna, Italy). Spatial density estimates are also needed to forecast potential vent locations within such distributed volcanic systems (Cappello et al 2011).

In addition, loci of activity may wax and wane with time, such that past vent patterns may not accurately forecast future vent locations (Condit and Connor 1996). Thus, it is important to determine if temporal patterns are present in the distribution of past events, so that an appropriate time interval can be selected for the analysis (i.e., use only those vents that represent likely future patterns of activity, not older vents that may represent past patterns).

Kernel density estimation is a non-parametric method for estimating the spatial density of future volcanic events based on the the locations of past volcanic events (Connor and Connor 2009; Kiyosugi et al 2010; Bebbington and Cronin 2010). Two important parts of the spatial density estimate are the kernel function and its bandwidth, or smoothing parameter. The kernel function is a probability density function that defines the probability of future vent formation at locations within a region of interest. The kernel function can be any positive function that integrates to one. Spatial density estimates using kernel functions are explicitly data driven. A basic advantage of this approach is that the spatial density estimate will be consistent with known data, that is, the spatial distribution of past volcanic events. A potential disadvantage of these kernel functions is that they are not inherently 
sensitive to geologic boundaries. If a geologic boundary is known it is possible to modify the density estimate with data derived from field observations and mapping. Connor et al (2000) and Martin et al (2004) discuss various methods of weighting density estimates in light of geological or geophysical information, in a manner similar to Ward (1994). A difficulty with such weighting is the subjectivity involved in recasting geologic observations as density functions.

A two-dimensional radially-symmetric Gaussian kernel for estimating spatial density is given by Silverman (1978); Diggle (1985); Silverman (1986); Wand and Jones (1995):

$$
\hat{\lambda}(\mathbf{s})=\frac{1}{2 \pi h^{2} N} \sum_{i=1}^{N} \exp \left[-\frac{1}{2}\left(\frac{d_{i}}{h}\right)^{2}\right]
$$

The local spatial density estimate, $\hat{\lambda}(\mathbf{s})$, is based on $N$ total events, and depends on the distance, $d_{i}$, to each event location from the point of the spatial density estimate, $\mathbf{s}$, and the smoothing bandwidth, $h$. The rate of change in spatial density with distance from events depends on the size of the bandwidth, which, in the case of a Gaussian kernel function, is equivalent to the variance of the kernel. In this example, the kernel is radially symmetric, that is, $h$ is constant in all directions. Nearly all kernel estimators used in geologic hazard assessments have been of this type (Woo 1996; Stock and Smith 2002; Connor and Hill 1995; Condit and Connor 1996). The bandwidth is selected using some criterion, often visual smoothness of the resulting spatial density plots, and the spatial density function is calculated using this bandwidth. A two-dimensional elliptical kernel with a bandwidth that varies in magnitude and direction is given by Wand and Jones (1995),

$$
\hat{\lambda}(\mathbf{s})=\frac{1}{2 \pi N \sqrt{|H|}} \sum_{i=1}^{N} \exp \left[-\frac{1}{2} \mathbf{b}^{T} \mathbf{b}\right]
$$

where,

$$
\mathbf{b}=\mathbf{H}^{-1 / 2} \mathbf{x} \text {. }
$$

Equation 1 is a simplification of this more general case, whereby the amount of smoothing by the bandwidth, $h$, varies consistently in both the N-S and E-W directions. The bandwidth, $\mathbf{H}$, on the other hand, is a 2 $\times 2$ element matrix that specifies two distinct smoothing patterns, one in a N-S trending direction and another in an $\mathrm{E}-\mathrm{W}$ trending direction. This bandwidth matrix is both positive and definite, important because the matrix must have a square root. $|\mathbf{H}|$ is the determinant of this matrix and $\mathbf{H}^{-1 / 2}$ is the inverse of its square root. $\mathbf{x}$ is a $1 \times 2$ distance matrix (i.e. the $x$-distance and $y$-distance from $\mathbf{s}$ to an event), $\mathbf{b}$ is the cross product of $\mathbf{x}$ and $\mathbf{H}^{-1 / 2}$, and $\mathbf{b}^{T}$ is its transform. The resulting spatial density at each point location, $\mathbf{s}$, is usually distributed on a grid that is large enough to cover the entire region of interest. Bandwidth selection is a key feature of kernel density estimation (Stock and Smith 2002; Connor et al 2000; Molina et al 2001; Abrahamson 2006; Jaquet et al 2008; Connor and Connor 2009), and is particularly relevant to lava flow hazard studies. Bandwidths that are narrow focus density near the locations of past events. Conversely, a large bandwidth may over-smooth the density estimate, resulting in unreasonably low density estimates near clusters of past events, and overestimate density far from past events. This dependence on bandwidth can create ambiguity in the interpretation of spatial density if bandwidths are arbitrarily selected. A further difficulty with elliptical kernels is that all elements of the bandwidth matrix must be estimated, that is the magnitude and direction of smoothing in two directions. Several methods have been developed for estimating an optimal bandwidth matrix based on the locations of the event data (Wand and Jones 1995), and have been summarized by Duong (2007). Here we utilize a modified asymptotic mean integrated squared error (AMISE) method, developed by Duong and Hazelton (2003), called the SAMSE pilot bandwidth selector, to optimally estimate the smoothing bandwidth for our Gaussian kernel function. These bandwidth estimators are found in the freely available R Statistical Package (Hornik 2009; Duong 2007). Bivariate bandwidth selectors like the SAMSE method are extremely useful because, although they are mathematically complex, they find optimal bandwidths using the actual data locations, removing subjectivity from the process. The bandwidth selectors used in this hazard assessment provide global estimates of density, in the sense that one bandwidth or bandwidth matrix is used to describe variation across the entire region.

Given that spatial density estimates are based on the distribution of past volcanic events, existing volcanic vents within a region and time period of interest first need to be identified and located. This compilation is then used as the basis for estimating the probability of the opening of new vents within a region. Our lava flow hazard assessment method is concerned with the likelihood of the opening of new vents that erupt lava flows. Such vents may form when magma first reaches the surface, forming a new volcano, or may form during an extended episode of activity, whereby multiple vents may form while an eruptive episode continues over some period of time, generally months to years (Luhr and Simkin 1993), and the locus of activity shifts as new dikes are injected into the shallowest part of the crust. Therefore, for the purposes of this study, an event is defined as the opening of a new vent at a new location during a new 
episode of volcanic activity. Multiple vents formed during a single episode of volcanism are not simulated.

\section{Numerical Simulation of Lava flows}

On land, a lava flow is a dynamic outpouring of molten rock that occurs during an effusive volcanic eruption when hot, volatile-poor, relatively degassed magma reaches the surface (Kilburn and Luongo 1993). These lava flows are massive volcanic phenomena that inundate areas at high temperature $\left(>800^{\circ} \mathrm{C}\right)$, destroying structures, even whole towns, by entombing them within meters of rock. The highly destructive nature of lava flows demands particular attention when critical facilities are located within their potential reach.

The area inundated by lava flows depends on the eruption rate, the total volume erupted, magma rheological properties, which in turn are a function of composition and temperature, and the slope of the final topographic surface (Dragoni and Tallarico 1994; Griffiths 2000; Costa and Macedonio 2005). Previous studies have modeled the physics of lava flows using the Navier-Stokes equations and simplified equations of state (Dragoni 1989; Del Negro et al 2005; Miyamoto and Sasaki 1997). Other studies have concentrated on characterizing the geometry of lava flows, and studying their development during effusive volcanic eruptions (Walker 1973; Kilburn and Lopes 1988; Stasiuk and Jaupart 1997; Harris and Rowland 2009). These morphological studies are mirrored by models that concentrate on the areal extent of lava flows, rather than their flow dynamics. These models generally abstract the highly complex rheological properties of lava flows using geometric terms and/or simplified cooling models (Barca et al 1994; Wadge et al 1994; Harris and Rowland 2001; Rowland et al 2005).

A new lava flow simulation code, written in PERL, was created to assess the potential for site inundation by lava flows, similar, in principle, to areal-extent models. This lava flow simulation tool is used to assess the probability of site inundation rather than attempting to model the complex real-time physical properties of lava flows. Since the primary physical information available for lava flows is their thickness, area, length and volume, this model is guided by these measurable parameters and not directly concerned with lava flow rates, their fluid-dynamic properties, or their chemical makeup and composition. The purpose of the model is to determine the conditional probability that flow inundation of a site will occur, given an effusive eruption at a particular location estimated using the spatial density model discussed previously.

A total volume of lava to be erupted is set at the start of each model run. The model assumes that each cell inundated by lava retains or accumulates a residual amount of lava. The residual must be retained in a cell before that cell will pass any lava to adjacent cells. This residual corresponds to the modal thickness of the lava flow. Lava may accumulate in any cell to amounts greater than this residual value if the topography allows pooling of lava. As flow thickness varies between lava flows, the residual value chosen for the flow model also varies from simulation to simulation. Here, our term residual corresponds to the term adherence, used in codes developed by Wadge et al (1994) and Barca et al (1994). In our case, residual lava does not depend on temperature or underlying topography, but rather, is used to maintain a modal lava flow thickness. Lava flow thicknesses, measured within the site area, are fit to a statistical distribution which is sampled stochastically in order to choose a residual (i.e. modal thickness) value for each realization. Lava flow simulation requires a digital elevation model (DEM) of the region of interest. One source of topographic DEM data is the Shuttle RADAR Topography Mission (SRTM) database. The 90-meter grid spacing of SRTM data limits the resolution of the lava flow. Topographic details smaller than $90 \mathrm{~m}$ can influence flow path, but these cannot be accounted for using a 90-m DEM. A more detailed DEM could provide enhanced flow detail, but a decrease in DEM grid spacing increases the total number of grid cells, thus increasing computation time as the flow has to pass through an increasing number of grid cells. A balance needs to be maintained between capturing important flow detail over the topography and limiting the overall time required to calculate the full extent of the flow. Critical considerations for grid spacing are the topography of the site area and the volumes and flow rates of local lava flows. Lava flows erupted at high rate or high viscosity would quickly overwhelm surrounding topography, so in these cases a coarse 90-m DEM may be sufficient for flow modeling. For low flow rates or low viscosities, lava flows would meander around smaller topographic features which would be unresolved in a coarse 90-m DEM. Therefore, in these cases a higher resolution DEM would be necessary to achieve credible model results. In our study, a 90-m DEM was considered adequate due to the unavailability of information regarding lava flow rates in the area and assumed higher flow rates based on flow geometries measured in the field. Also, the boundaries of the plateau on which the ANPP site is located was determined to be adequately resolved by a $90-\mathrm{m}$ DEM.

A simple algorithm is used to distribute the lava from a source cell to each of its adjacent cells once the residual of lava has accumulated. Adjacent cells are defined as those cells directly north, south, east and west of a source cell. For ease of calculation, volumes are changed to thicknesses. Cells that receive lava are added to a list of active cells to track relevant properties regarding cell state, including: location within the DEM, current lava thickness, and initial elevation. Active cells have one 
parent cell, from which they receive lava, and up to 3 neighbor cells which receive their excess lava. A cell becomes a neighbor only if its effective elevation (i.e. lava thickness + original elevation) is less than its parent's effective elevation. If an active cell has neighbors, then its excess lava is distributed proportionally to each neighbor based on the effective elevation difference between the active cell and each of its neighbors. Lava distribution can be summarized with the following equation:

$$
L_{n}=X_{a} D_{n} / T
$$

where $L_{n}$ refers to the lava thickness in meters received by a neighbor, $X_{a}$ is the excess lava thickness an active cell has to give away. $D_{n}$ is the difference in the effective elevation between an active cell and a neighboring cell, $D_{n}=E_{a}$ - $E_{n}$, where $E_{a}$ refers to the effective elevation of the active cell and $E_{n}$ refers to the effective elevation of an adjacent neighbor. The effective elevation is defined as the thickness of lava in a cell plus its original elevation from the DEM. $T$, is the total elevation difference between an active cell and all of its adjacent neighbors, $1-N$,

$$
T=\sum_{n=1}^{N} D_{n} .
$$

Iterations continue until the total flow volume is depleted. Some example lava flows simulated in this fashion are shown in Figure 2.

\section{Lava flow hazard at the Armenian nuclear power plant site}

Lava flows are a common feature of the Armenian landscape. Some mapped flows are highlighted in Figure 2. A group of 18 volcanic centers comprise an area known as the Shamiram Plateau (this area is located within the red box in Figure 1). The Armenian nuclear power plant (ANPP) site lies within this comparatively dense volcanic cluster at the southern margin of the Shamiram Plateau. Our lava flow hazard assessment is designed to assess the conditional probability that lava flows reach the boundary of the site area, given an effusive eruption on the Shamiram Plateau. In addition, large-volume lava flows are found on the flanks of Aragats volcano, a 70-km-diameter basalt-trachyandesite to trachydacite volcano located immediately north of the Shamiram Plateau.

The mapped lava flows on the Shamiram Plateau can be divided into two age groups, pre-ignimbrite lava flows that range in age from approximately $0.91-1.1 \mathrm{Ma}$, and post-ignimbrite lava flows that cover the ignimbrites of Aragats volcano. The youngest features of Aragats Volcano are large volume lava flows from two cinder cones, Tirinkatar $(0.45 \mathrm{Ma})$ and Ashtarak (0.53 Ma). All of these age determinations are based on K-Ar dating by
Chernyshev et al (2002). The youngest small-volume lava flows of the Shamiram Plateau are the Dashtakar group of cinder cones, based on borehole evidence indicating that the Dashtakar flows overlay one of these ignimbrites of Aragats.

Lava flows of the Shamiram Plateau are typical of monogenetic fields, being of comparatively low volume, generally $<0.03 \mathrm{~km}^{3}$, and short total length, generally $<$ $5 \mathrm{~km}$. Based on logging data from four boreholes and including the entire area of the Shamiram Plateau and estimated thickness of the lava pile, the total volume of lava flows making up the plateau is $\sim 11-24 \mathrm{~km}^{3}$. Given these values, hundreds of individual lava flows comprise the entire plateau. Thus, there is a possibility that lava flows will inundate the site in the future, associated with the eruption of monogenetic volcanoes on the Shamiram Plateau, should such eruptions occur.

Mapped lava flows of the Shamiram Plateau are volume-limited flows (Kilburn and Lopes 1988; Stasiuk and Jaupart 1997; Harris and Rowland, 2009), trachyandesite to trachydacite in composition. Lengths range from $1.4 \mathrm{~km}$, from Shamiram volcano, to $2.49 \mathrm{~km}$ from Blrashark volcano; volumes range from $3 \times 10^{-3} \mathrm{~km}^{3}$, from Karmratar volcano, to $2.3 \times 10^{-2} \mathrm{~km}^{3}$ from Atomakhumb volcano (Table 1).

Volume-limited flows occur when small batches of magma reach the surface and erupt for a brief period of time, forming lava flows associated with individual monogenetic centers. These eruptions often occur in pulses and erupting vents may migrate a short distance, generally $<1 \mathrm{~km}$, during the eruption. Each pulse of activity in the formation of the monogenetic center may produce a new individual lava flow, hence, constructing a flow field over time. The longest lava flows in these fields are generally those associated with the early stages of the eruption, when eruption rates are greatest (Kilburn and Lopes, 1988). Within the Shamiram Plateau area, individual monogenetic centers have one (e.g. Shamiram volcano) to many (e.g. Blrashark volcano) individual lava flows.

Longer lava flows are also found on Aragats volcano, especially higher on its flanks (Table 1). These summit lavas comprise a thick sequence of trachyandesites and trachydacites having a total volume $>500 \mathrm{~km}^{3}$. The most recent lava flows from the flanks of Aragats include Tirinkatar, which is separated into two individual trachybasalt flows Tirinkatar-1 and Tirinkatar-2, and the Ashtarak lava flow. Tirinkatar-1 and Ashtarak each have volumes $\sim 0.5 \mathrm{~km}^{3}$. The largest volume flank lava flows are part of the trachydacitic Cakhkasar lava flow of Pokr Bogutlu volcano, with a total volume $\sim 18 \mathrm{~km}^{3}$, on the same order as the largest historical eruptions of lava flows worldwide (Thordarson and Self 1993). These larger volume lava flows are effusion rate-limited, since the 


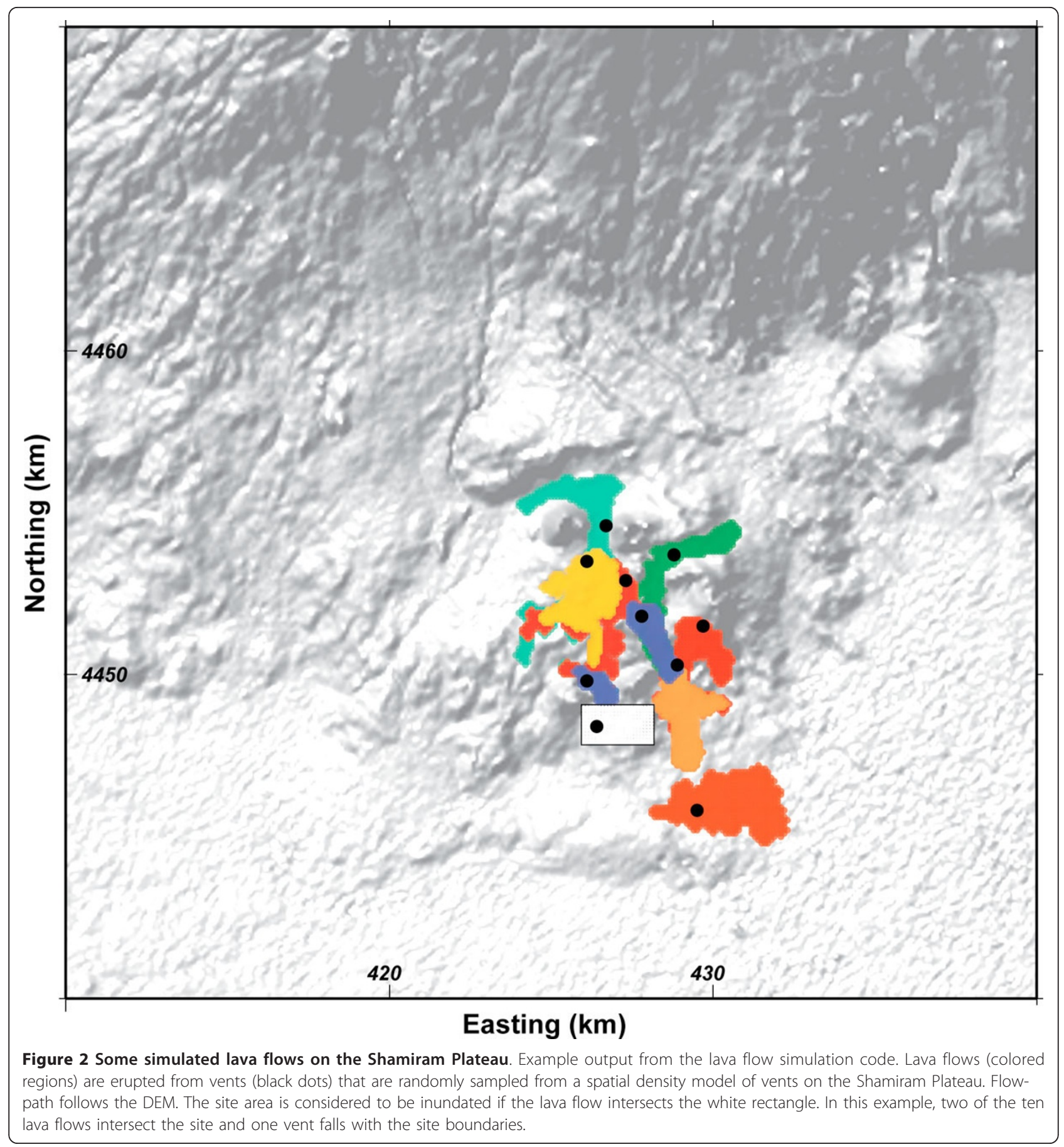

length of the lava flow is controlled by the effusion rate at the vent. The lengths of the Ashtarak and Tirinkatar-1 lava flows exceed $20 \mathrm{~km}$. Based on comparison with observed historical eruptions, their effusion rates were likely on the order of $100 \mathrm{~m}^{3} \mathrm{~s}^{-1}$ (Walker, 1973; Malin 1980; Kilburn and Lopes, 1988; Harris and Rowland, 2009). Thus, while volume-limited flows erupt on the Shamiram Plateau in the immediate vicinity of the site, effusion rate-limited flows erupt at higher elevations on the flanks of Aragats volcano. While it is conceivable that these larger volume flows may reach the site because of their great potential length, this event is less likely because their occurrence is so infrequent. Another deterrent is the fact that the Shamiram plateau acts as a topographic barrier to these longer, larger flows reaching the ANPP site. Each class of lava flows, smaller volume-limited 
Table 1 Size estimates of lava flows

\begin{tabular}{|c|c|c|c|c|c|}
\hline $\begin{array}{l}\text { Volcano } \\
\text { (source) } \\
\end{array}$ & $\begin{array}{l}\text { Area } \\
\left(\mathrm{km}^{2}\right)\end{array}$ & $\begin{array}{r}\text { Thickness } \\
(\mathrm{m})\end{array}$ & $\begin{array}{r}\text { Volume } \\
\left(\mathrm{km}^{3}\right)\end{array}$ & $\begin{array}{r}\text { Length } \\
(\mathrm{km})\end{array}$ & Composition \\
\hline Arich & 16.3 & 8 & 0.130 & 9.48 & $\mathrm{~TB}^{1}, \mathrm{BTA}^{1}$ \\
\hline Atomakhumb & 3.9 & 6 & 0.023 & 3.43 & $\mathrm{BA}^{1}, \mathrm{BTA}$ \\
\hline Barcradir(Bartsradir) & 32.9 & 9 & 0.296 & 12.10 & TB, BTA \\
\hline Bazmaberd & 13.1 & 14 & 0.184 & 6.34 & BA, BTA \\
\hline Blrashark & 1.6 & 6 & 0.010 & 2.49 & $T A^{1}, T D^{1}$ \\
\hline Blrashark & 2.5 & 7 & 0.018 & 3.13 & TA, TD \\
\hline Bolorsar & 2.2 & 6 & 0.013 & 2.72 & BTA, TA \\
\hline Dashtakar & 2.1 & 10 & 0.021 & 4.44 & BA, BTA \\
\hline Dashtakar & 1.6 & 6 & 0.009 & 3.66 & BA, BTA \\
\hline Karmratar & 0.7 & 4 & 0.003 & 3.61 & TA \\
\hline Mets Mantash & 8.9 & 9 & 0.080 & 8.47 & TB, BTA \\
\hline Shamiram & 1.0 & 4 & 0.004 & 1.41 & TA \\
\hline Siserasar & 0.8 & 11 & 0.009 & 1.72 & TA \\
\hline Tirinkatar-2 & 13.3 & 4 & 0.053 & 6.54 & BTA, BA \\
\hline Topqar(Topkar) & 2.9 & 9 & 0.026 & 3.07 & BTA, TA \\
\hline Ashtarak & 84 & 6 & 0.50 & 26.50 & BA, BTA \\
\hline Irind & 66 & 55 & 3.65 & 20.53 & Dacite \\
\hline Paros & 109 & 8 & 0.87 & 33.36 & TB, BTA \\
\hline Tirinkatar-1 & 75 & 7 & 0.53 & 26.36 & BTA, BA \\
\hline Pokr Bogutlu & 165 & 110 & 18.18 & 27.92 & TD \\
\hline (Cakhkasar) & & & & & \\
\hline
\end{tabular}

${ }^{1}$ Note: TB (trachybasalt), BTA (basalt-trachyandesite),

BA (basaltic-andesite),TA (trachyandesite), TD (trachydacite)

The volcanic rock nomenclature follows the one of Le Bas et al (1986)

Size estimates for some lava flows associated with monogenetic vents of the Shamiram Plateau and elsewhere on the flanks of Aragats volcano. The input parameters for the lava flow simulations were based on the observed characteristics of the smaller-volume flows. Volcanoes located within the area of the Shamiram Plateau appear in italic font. Size estimates for the 5 largest lava flows on the flanks of Aragats volcano are listed last.

flows and larger effusion rate-limited flows, is considered separately when assessing lava flow hazard at the ANPP site.

\section{Results and Discussion}

\section{Using spatial density estimation}

Locating the source region of erupting lava is critical in determining the area inundated by a lava flow. Probable source regions are estimated using a spatial density model, which in turn depends on a geological map identifying the locations of past eruptive vents. In this context, volcanic vents are defined as the approximate locations where magma has or may have reached the surface and erupted in the past. A primary difficulty in using a data set of the distribution of volcanic vents is determination of independence of events. In statistical parlance, independent events are drawn from the same statistical distribution, but the occurrence of one event does not influence the probability of occurrence of another event. We are interested in constructing a spatial density model only using independent events. Unfortunately, it is difficult to determine from mapping and stratigraphic analysis if vents formed during the same eruptive episode or occurred as independent events during different volcanic eruptions. Some of these are easily recognized (e.g. boccas that are located adjacent to scoria cones). In other cases, it is uncertain if individual volcanoes should be considered to be independent events, or were in reality part of the same event. Because of this uncertainty, alternative data sets are useful when estimating the spatial density. Here, we use one data set to maximize the potential number of volcanic events: all mapped vents are included in the data set as independent events. An alternative data set could consider volcanic events to be comprised of groups of volcanic vents that are closely spaced and not easily distinguished stratigraphically.

In order to apply the spatial density estimate, it is assumed that 18 mapped volcanic centers represent the potential distribution of future volcanic vents on the Shamiram Plateau. Some older vents are no doubt buried by subsequent volcanic activity. It is also possible that older vents are buried in sediment of the Yerevan basin, south of the ANPP site.

Using a data set that includes 18 volcanic events mapped on the Shamiram Plateau (Table 2), the SAMSE selector yields the following optimal bandwidth matrix 
Table 2 Volcanic vents mapped on the Shamiram Plateau

\begin{tabular}{ll}
\hline Easting & Northing \\
\hline 425507 & 4449732 \\
425649 & 4449144 \\
425992 & 4449400 \\
425053 & 4449362 \\
428682 & 4452894 \\
429363 & 4452946 \\
429504 & 4452711 \\
429931 & 4452251 \\
427322 & 4449676 \\
427383 & 4449840 \\
427835 & 4450008 \\
428332 & 4444255 \\
427386 & 4454344 \\
427538 & 4453062 \\
430618 & 4442102 \\
427623 & 4452343 \\
426857 & 4451520 \\
425285 & 4454652 \\
\hline
\end{tabular}

The location of 18 volcanic events used in the spatial density analysis of future volcanism on the Shamiram Plateau, units are UTM meters. These vent locations are used to determine a closer-to-optimal data-driven bandwidth.

and corresponding square root matrix:

$$
\mathbf{H}=\left[\begin{array}{cc}
0.84 & -0.01 \\
-0.01 & 2.1
\end{array}\right] \quad \sqrt{\mathbf{H}}=\left[\begin{array}{cc}
0.92 & -0.005 \\
-0.005 & 1.5
\end{array}\right]
$$

In equation 4 , the upper left and lower right diagonal elements represent smoothing in the $\mathrm{E}-\mathrm{W}$ and $\mathrm{N}-\mathrm{S}$ directions, respectively. The $\sqrt{\mathbf{H}}$ indicates an actual E-W smoothing distance of $920 \mathrm{~m}$ and a N-S smoothing distance of $1500 \mathrm{~m}$. A N-S ellipticity is reflected in the overall shape of the bandwidth (Figure 3). The resulting spatial density map is contoured in Figure 4.

\section{A grid-based flow regime}

The SRTM database from CGIAR-CSI (the Consultative Group on International Agricultural Research-Consortium for Spatial Information) is used as a model of topographic variation on the Shamiram Plateau and adjacent areas. This consortium (Jarvis et al, 2008) has improved the quality of SRTM digital topographic data by further processing version 2 (released by NASA in 2005) using hole-filling algorithms and auxiliary DEMs to fill voids and provide continuous topographical surfaces. For the lava flow simulation, these data are converted to a UTM Zone $38 \mathrm{~N}$ projection, using the USGS program, PROJ4, and re-sampled at a $100 \times 100 \mathrm{~m}$ grid spacing, using the mapping program GMT. In the model, lava is distributed from one $100 \mathrm{~m}^{2}$ grid cell to its adjacent grid cells.

The region that was chosen for the lava flow model is identified in Figure 1 (red-dashed box). Within this area a new vent location is randomly selected based on a

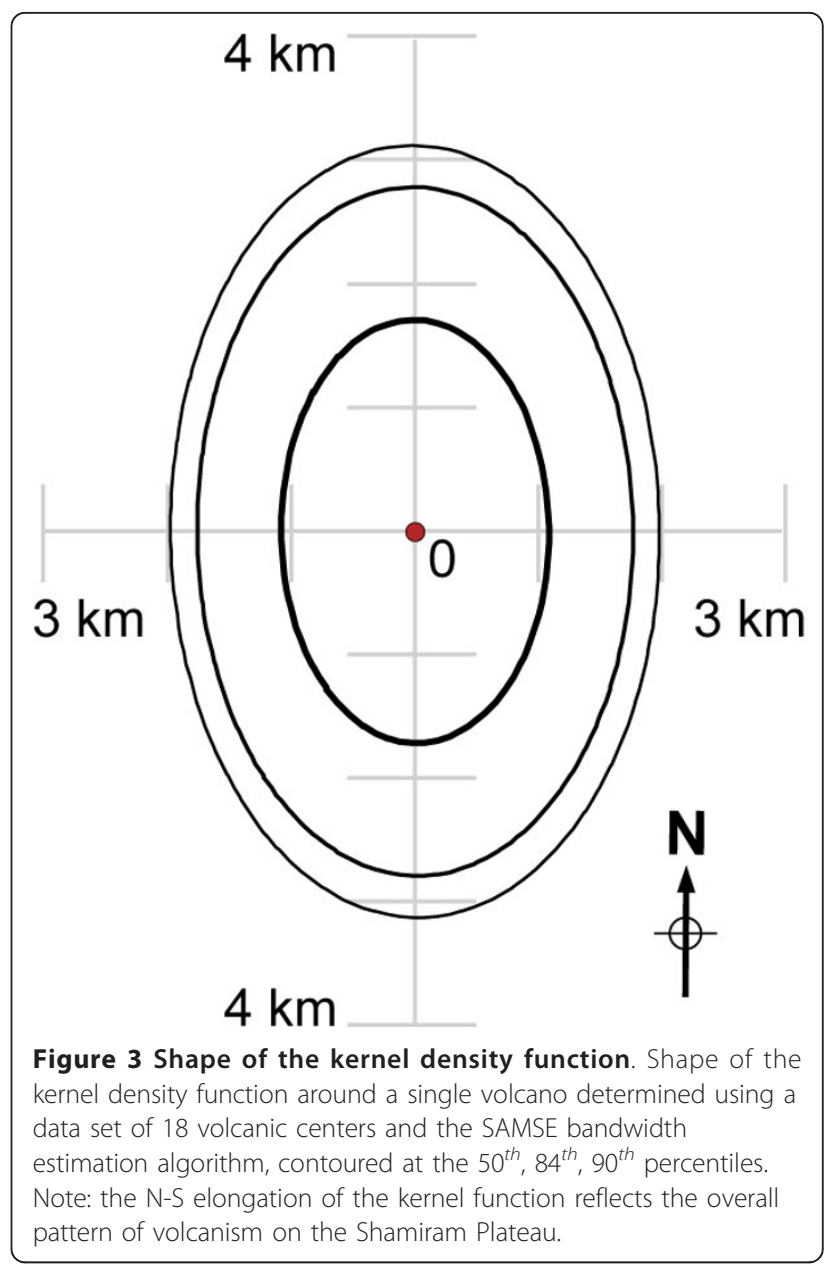

spatial density model of 18 events clustered within and around the Shamiram Plateau (Figure 4). The model simulates a flow of lava from this new vent location onto the surrounding topography. The total volume of lava to be erupted is specified at the onset of a model run. Lava is added incrementally to the DEM surface at the vent location until the total specified lava flow volume is reached. At each iteration, $10^{5} \mathrm{~m}^{3}$ is added to the grid cell at the location of the vent (source) and is distributed over adjoining grid cells. Given that a grid cell is $100 \mathrm{~m}^{2}$, this corresponds to adding a total depth of $10 \mathrm{~m}$ to the vent cell at each iteration.

The lava flow simulation is not intended to mimic the fluid-dynamics of lava flows, so these iterations are only loosely associated with time steps. For example, volumelimited lava flows of the Shamiram Plateau are generally < $5 \mathrm{~km}$ in length, with volumes on the order of $0.3-2.3 \times$ $10^{-2} \mathrm{~km}^{3}$. These volumes and lengths agree well with lavas from compilations by Malin (1980) and Pinkerton and Wilson (1994). For such lava flows, effusion rates of $10-100$ $\mathrm{m}^{3} \mathrm{~s}^{-1}$ are expected (Harris and Rowland, 2009). Using these empirical relations, an iteration adding a volume of 


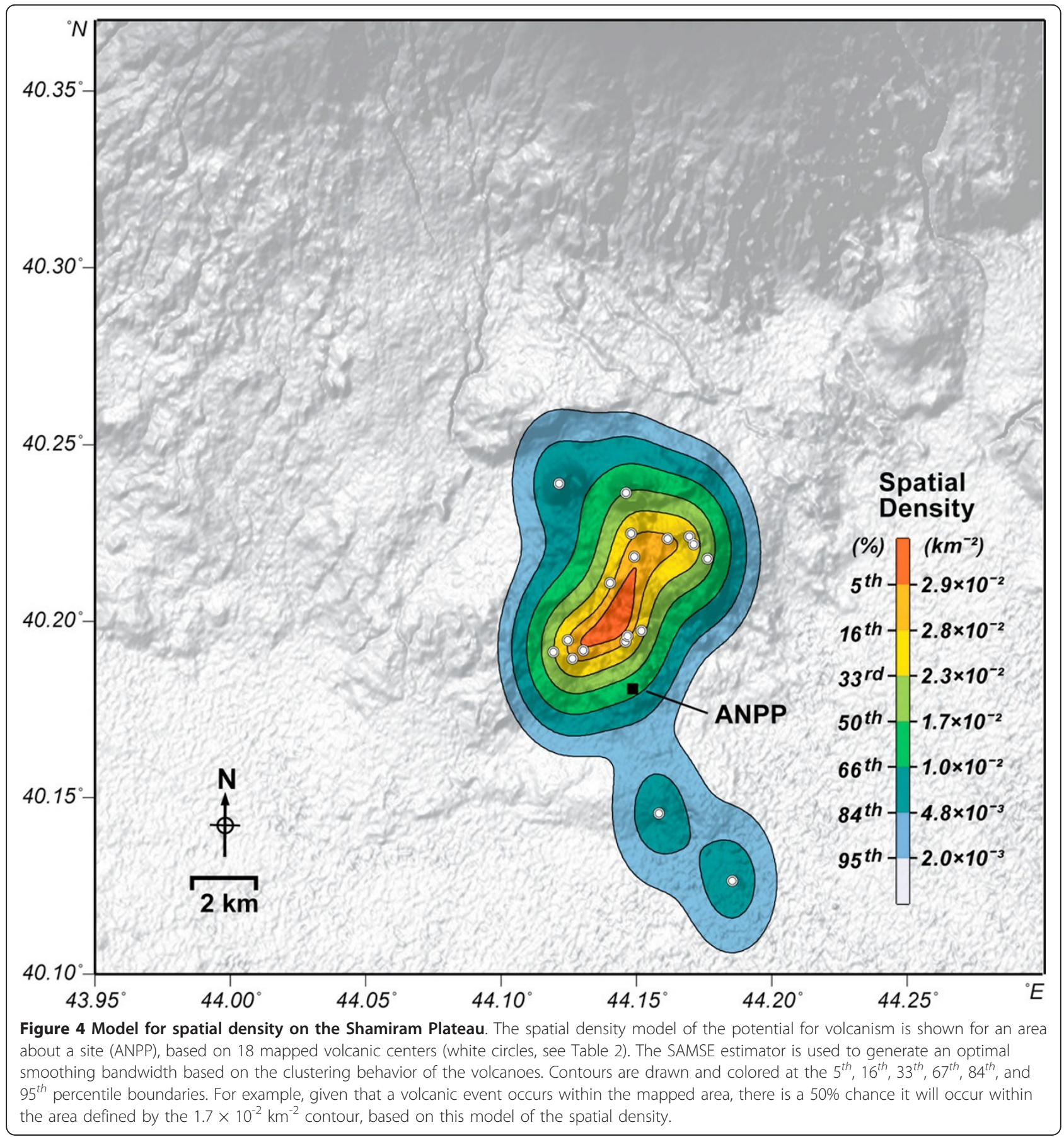

$10^{5} \mathrm{~m}^{3}$ of lava corresponds to an elapsed time of $10^{3}-10^{4} \mathrm{~s}$. Lava is distributed to adjacent cells only at each iteration, so this effusion rate corresponds to flow-front velocity on the order of $0.01-0.1 \mathrm{~ms}^{-1}$, in reasonable agreement with observations of volume-limited flow-front velocities.

\section{Parameter estimation for Monte Carlo simulation}

Many simulations are required to estimate the probability of site inundation by lava. Lava flow paths are significantly affected by the large variability in possible lava flow volumes, lava flow lengths, and complex topography. A computing cluster is used to execute this large number of simulations in a timely manner. Based on the volumes of some lava flows measured within and surrounding the Shamiram Plateau (Table 1), the range of flow volumes for the simulated flows was determined to be log-normally distributed, with a $\log ($ mean $)$ of $7.2\left(10^{7.2} \mathrm{~m}^{3}\right)$ and a $\log$ (standard deviation) of 0.5. Based on these observations, 
the lava flow code stochastically chooses a total erupted lava volume from a truncated normal distribution with a mean of 7.2, a standard deviation of 0.5 , and truncated at $\geq 6$ and $\leq 9$ (Table 3)). This range favors eruptions with smaller-volume flows, but also allows rare, comparatively larger-volume flows.

The input parameters to the lava flow code that are used to estimate the probability of inundation of the site are shown in Table 4. The boundary of the ANPP site is taken as a rectangular area, $2.6 \mathrm{~km}^{2}$. For the purposes of the simulation, it is assumed that if a lava flow crosses this perimeter, the site is inundated by lava. The lava flow simulation is based on the eruption of one lava flow, or cooling unit, from each vent. Based on the distribution of flow thickness values from 15 observed lava flows, within and surrounding the Shamiram Plateau, the code stochastically chooses a value for modal lava flow thickness from a truncated normal distribution having a mean of $7.0 \mathrm{~m}$, a standard deviation of $3.0 \mathrm{~m}$, and truncated at $\geq 4 \mathrm{~m}$ and $\leq 15 \mathrm{~m}$ (Figure 5). Lava residual is the amount of lava retained in each active cell, and is directly related to the modal thickness of the lava flow.

In reality, more than one lava flow may erupt during the course of formation and development of a single monogenetic volcano. However, the first lava flow to form during this eruption will tend to have the longest length and greatest potential to inundate the ANPP site. Experiments were conducted to simulate the formation of multiple (up to 10) lava flows from a single vent, or group of closely spaced vents. It was determined that the later lava flows tend to broaden the flow field, but not lengthen it. This result is in agreement with

Table 3 Lava flow simulation input parameters

\begin{tabular}{|c|c|c|}
\hline Parameter & Range & Notes \\
\hline ANPP site boundary & & Boundaries used in analysis \\
\hline East (km) & 428.2 & \\
\hline West (km) & 426.0 & \\
\hline North (km) & 4449.0 & \\
\hline South (km) & 4447.0 & \\
\hline \multirow[t]{3}{*}{ Lava thickness (m) } & $4-15$ & Truncated normal distribution; \\
\hline & & Mean $=7.0 \mathrm{~m}$ \\
\hline & & Standard Dev. $=3.0 \mathrm{~m}$ \\
\hline \multirow[t]{2}{*}{ Lava flow volume $\left(\mathrm{m}^{3}\right)$} & $10^{6}-10^{9}$ & $\begin{array}{l}\text { Truncated normal distribution; } \\
\text { (log)Mean }=7.2\end{array}$ \\
\hline & & $(\log )$ Standard Dev. $=0.5$ \\
\hline Iteration volume & $10^{5}$ & $\begin{array}{l}\text { Lava volume added at source } \\
\text { vent in each iteration }\end{array}$ \\
\hline Number of simulations & 10000 & \\
\hline
\end{tabular}

Input parameters used in the Monte Carlo simulation of lava flow inundation of the ANPP site by flows originating on or near the Shamiram Plateau. Flow thickness and volume are based on observed thicknesses and volumes of lava flows located on and surrounding the Shamiram Plateau. A probability

distribution is assigned to each of these two parameters based on the binned distribution of measured observations (Figure 5).
Table 4 Configuration file for lava flow simulation of vents on the Shamiram Plateau

\begin{tabular}{|c|c|}
\hline Parameter $=$ Value & Explanation \\
\hline \multicolumn{2}{|l|}{ Inputs } \\
\hline DEM_SOUTH $=4440$ & $N, S, E, W$ \\
\hline DEM_NORTH $=4470$ & boundaries \\
\hline DEM_EAST $=440$ & of the DEM \\
\hline \multicolumn{2}{|l|}{ DEM_WEST $=410$} \\
\hline DEM_SPACING $=0.1$ & DEM grid spacing $(\mathrm{km})$ \\
\hline DEM_FILE $=$ file & $\begin{array}{l}\text { (ASCll format) rows of elevation values } \\
\text { (masl) }\end{array}$ \\
\hline RESIDUAL_AV $=8.0$ & Lava thickness (m): Average \\
\hline \multirow[t]{2}{*}{ RESIDUAL_SD2 = 1.0} & Standard Deviation \\
\hline & (higher value=higher lava viscosity) \\
\hline \multirow[t]{2}{*}{ ERUPTED_LAVA $=1 \mathrm{e} 5$} & Volume of lava distributed \\
\hline & per iteration or pulse $\left(\mathrm{m}^{3}\right)$ \\
\hline TOTAL_LAVA_AV $=1 \mathrm{e} 7$ & Lava volume $\left(\mathrm{m}^{3}\right)$ : Average \\
\hline TOTAL_LAVA_SD2 $=0.5$ & Standard Deviation \\
\hline FLOWS $=1$ & $\begin{array}{l}\text { Number of lava flows to simulate per } \\
\text { run }\end{array}$ \\
\hline RUNS $=10000$ & $\begin{array}{l}\text { Number of lava flow runs (for statistical } \\
\text { analysis) }\end{array}$ \\
\hline AOI_WEST $=426.0$ & Area of interest \\
\hline \multicolumn{2}{|l|}{ AOI_EAST $=428.2$} \\
\hline \multicolumn{2}{|l|}{ AOI_SOUTH $=4447.8$} \\
\hline \multicolumn{2}{|l|}{ AOI_NORTH $=4449.0$} \\
\hline SPATIAL_DENSITY_FILE = file & $\begin{array}{l}X Y Z \text { format, grid of spatial density } \\
\text { values for the potential of volcanism }\end{array}$ \\
\hline SPATIAL_DENSITY_SPACING=.1 & spacing of spatial density grid (km) \\
\hline
\end{tabular}

Configuration file for simulated lava flows. The format of this ASCII file is parameter $=$ value. The shown values reflect the range of values used for the lava flow hazard assessment on the Shamiram Plateau.

observations of lava flow field development on Mt. Etna (Kilburn and Lopes, 1988). For the ANPP site, the conditional probability of site inundation was sensitive to lava flow length, but insensitive to broadening of the lava flow field. Therefore, only one lava flow was simulated per eruptive vent. Nevertheless, for some sites the potential for broadening the area of inundation by successive flows may be an important factor.

\section{Simulation results}

A total of 10000 simulations were executed in order to estimate the probability of lava flow inundation resulting from the formation of new monogenetic vents on the Shamiram Plateau. Out of 10000 events, 2485 of the simulated flows crossed the perimeter of the site, or $24.9 \%$ percent of the total number of simulations.

The distribution of simulated vent locations for the lava flow simulation is shown in Figure 6. Lava flows erupting from the central part of the Shamiram Plateau, up to $6 \mathrm{~km}$ north of the ANPP site, have a much greater potential of inundating the site area than lava flows originating from south, east, or west of the site. The central part of the 

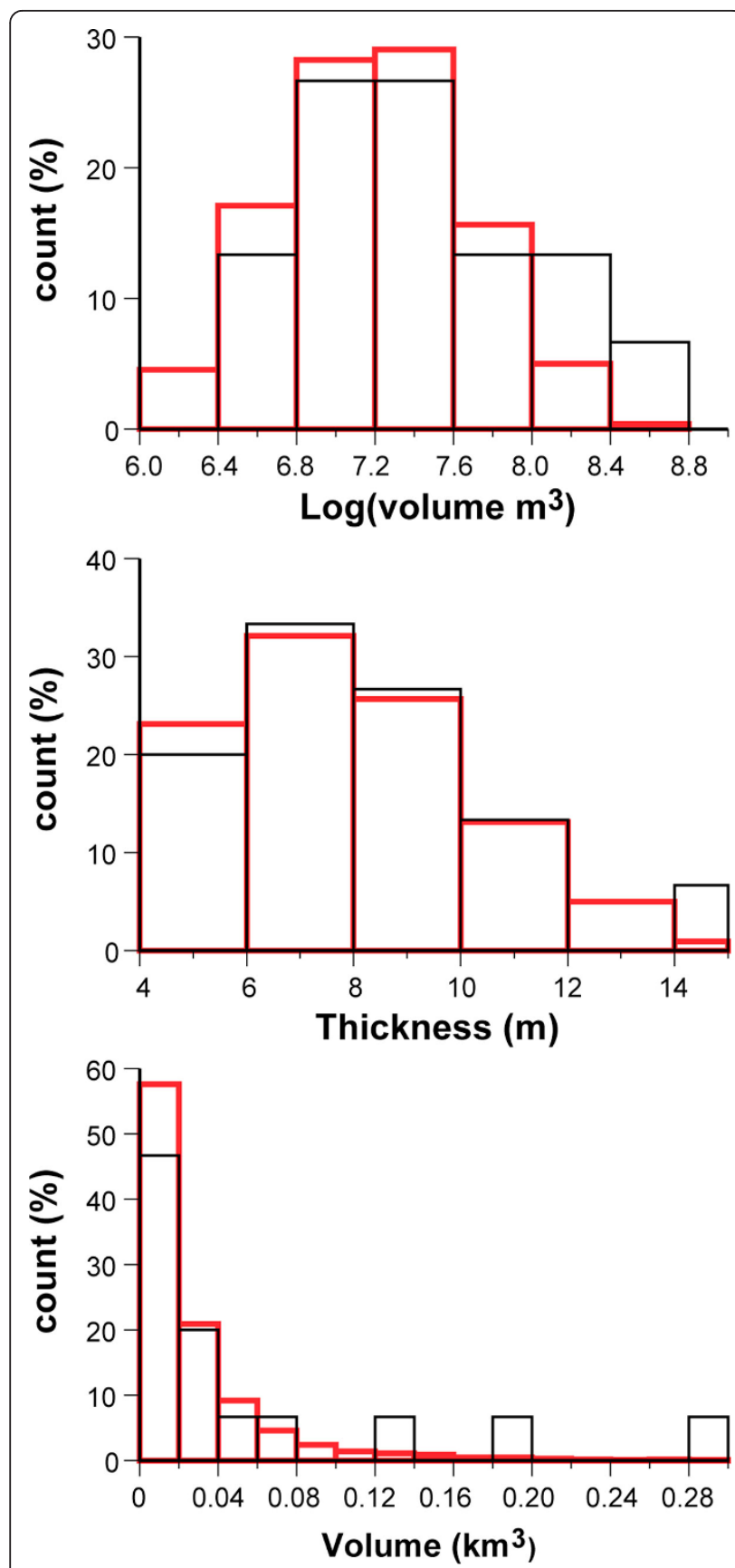

Figure 5 Histograms showing lava flow thickness, volume, and log(volume). Histograms showing the ranges of observed and simulated lava flow thickness, volume, and log(volume). Black bins characterize 15 observed lava flows. Flow thickness follows a normal distribution and volume follows a log-normal distribution. These field observations are summarized in Table 1. Red bins characterize 10000 flow thicknesses, randomly selected from a truncated normal distribution with a mean of 7 and a standard deviation of 3 , truncated above $4 \mathrm{~m}$ and below $15 \mathrm{~m}$. Similarly, flow volumes, were generated by random selection of their logarithms from a truncated normal distribution with a mean of 7.2 and a standard deviation of 0.5, truncated above 6 and below 9 (Table 3). These plots show that the distributions chosen for the Monte Carlo simulation reasonably match the range of observed values.
Shamiram Plateau is the most likely location of future eruptions, based on the spatial density analysis. Substantial topographic barriers to the south, east, and west block lava flows from inundating the site from these directions, and the probability of vent formation in these locations is much lower.

In order to test model validity against available geologic data from the region, a comparison was made of measured thickness, area, and $\log$ (volume) versus lava flow length for each observed lava flow (Figure 7). The same comparison was made for each simulated lava flow. Lava flow length for each flow, simulated and observed, was calculated as follows. First, the lava flow mid-point was estimated along E-W line segments drawn across the flow at regular intervals. The distance between these mid-points was summed along the N-S extent of the lava flow. Second, the same procedure was used but midpoints were calculated along N-S line segments and the distance between mid-points was summed along the E-W direction. The longer of the two distances was taken to be the length of the lava flow. This method provided an objective comparison between observed and simulated flow lengths. As shown in Figure 7, the simulated lava flow volumes, thicknesses, and areal extents all fall within the ranges of values measured in the field.

Larger-volume lava flows were simulated for flank eruptions of Aragats volcano. For these simulations a trachyandesite to trachybasalt composition was assumed. This flow regime mimics a effusion rate-limited lava flows, with lava thicknesses (or lava residuals) ranging from approximately 6-9 $\mathrm{m}$. This flow geometry is consistent, for example, with the Tirinkatar-1, Ashtarak, and Paros lava flows. The total volumes of these simulated flows range from approximately $5 \times 10^{8} \mathrm{~m}^{3}\left(0.5 \mathrm{~km}^{3}\right)$ to $8.7 \times 10^{8} \mathrm{~m}^{3}\left(0.87 \mathrm{~km}^{3}\right)$. An additional spatial density estimate was made to define the probability of future vent formation on the flanks of Aragats volcano. This model is based on the locations of 27 vents located on the flanks of Aragats volcano (Table 5). This spatial density estimate was used to initialize simulated lava flows originating from flank vents to assess the hazard of largevolume, effusion rate-limited flank lava flows. Since the details of these flank lava flows have been very poorly documented (only 5 have been classified by thickness, volume, and length) an accurate statistical analysis of these parameters was not considered. Rather, values for volume and thickness were randomly selected from those trachyandesite to trachybasalt flank flows that were measured in the field. The configuration parameters for this flank lava flow simulation regime is detailed in Table 6 . Approximately 1000 flows were simulated based on a pattern of volcanism defined by the spatial density model shown in Figure 8. These flows required more run-time than the smaller-volume Shamiram flows because of the 


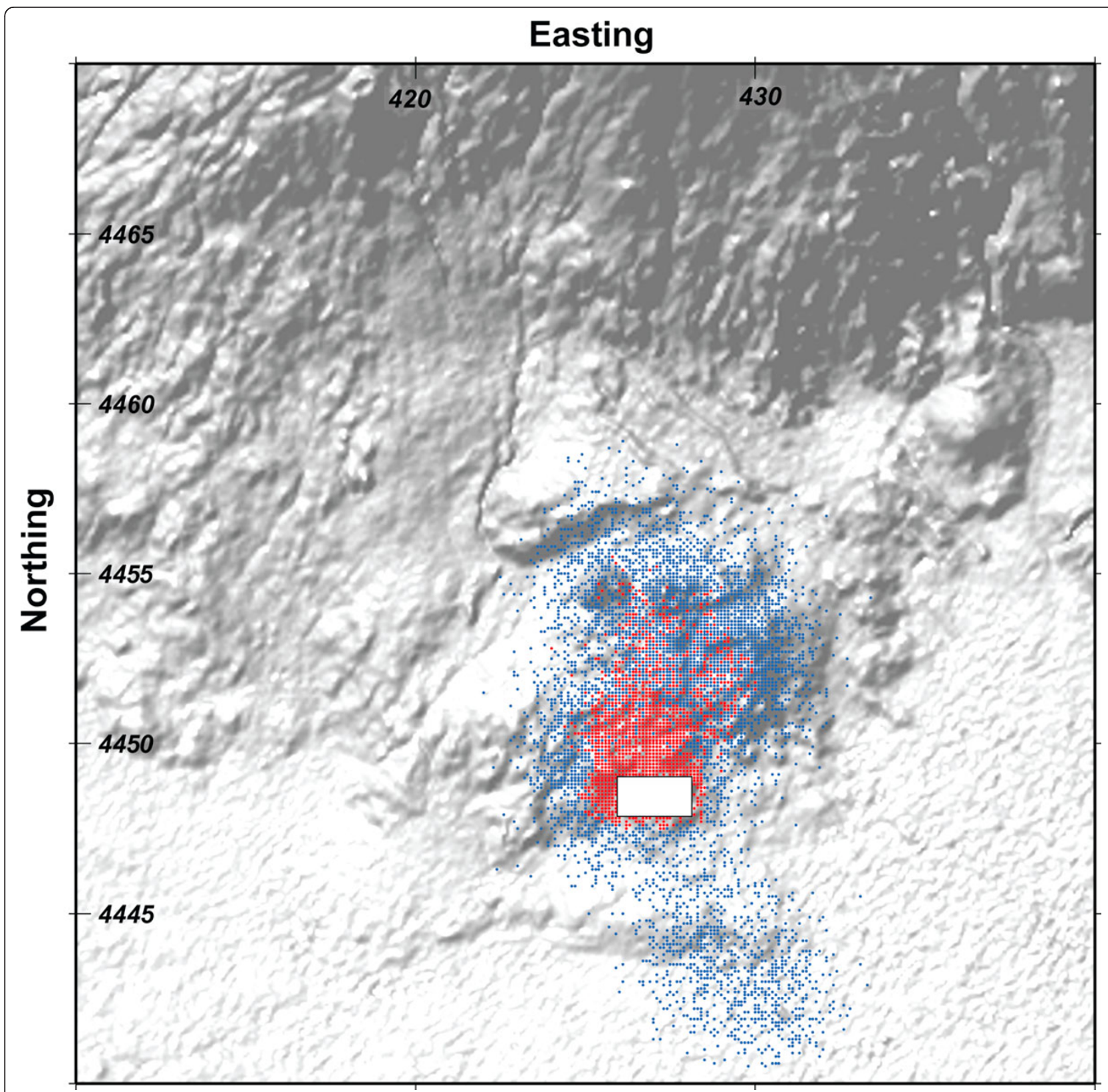

Figure 6 Results of Monte Carlo simulation of lava flow inundation of the site. Results of Monte Carlo simulation of lava flow inundation of the site (white box). Vent locations for lava flows that inundated the ANPP site are shown as red dots. Blue dots indicate the vent locations from which lavas did not inundate the ANPP site. Most lava flows that inundate the site originate on the central part of the Shamiram Plateau, north of the ANPP site.

greater number of grid cells inundated. None of the simulated flows erupted on the flanks resulted in inundation of the ANPP site. The Shamiram Plateau creates an effective topographic barrier to these lava flows diverting drainage of lava west or east of the plateau. Therefore, although impressive in length and volume, the ANPP site is not likely to be inundated by long lava flows emitted from the flanks of Aragats volcano. Since these long lava flows do not represent a credible hazard to the ANPP site, a larger Monte Carlo simulation (greater than 1000 runs) and separate statistical analysis of effusion rate-limited lava flows high on the flanks of Mt. Aragats, was not performed. Two examples of effusion rate-limited flows are diagrammed in Figure 9.

\section{Conclusions}

We demonstrate a methodology for site-specific lava flow hazard assessment. This two-stage process uses a 

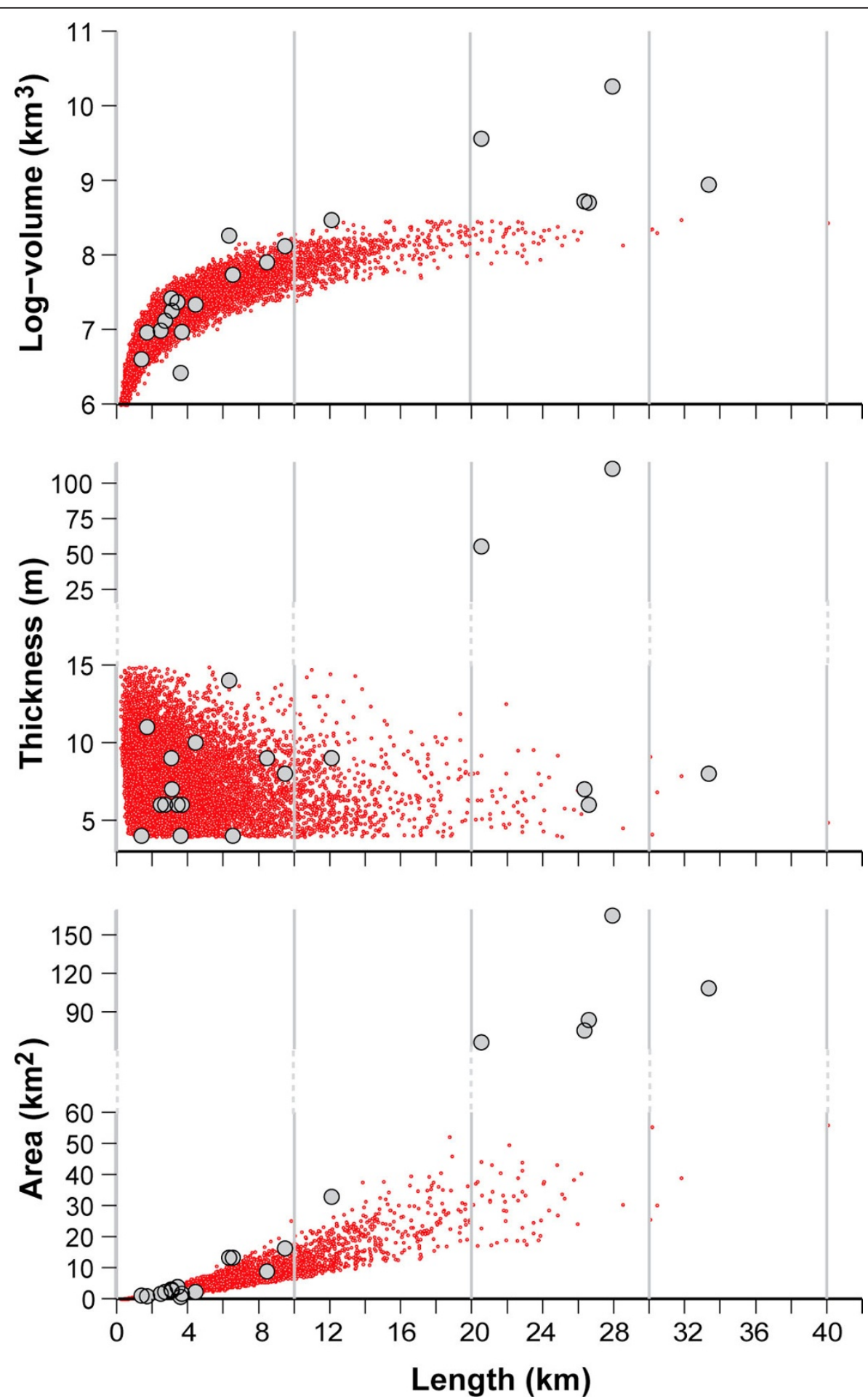

Figure 7 Plots of length versus area, thickness, and log(volume) for observations and simulations. Plots of lava flow length versus area, thickness, and log(volume) include field observations (gray dots) and computer simulations (red points). Each plot shows results of 10000 lava flow simulations, generated using the probability distributions shown in Figure 5 and specified in Table 3. Field observations of 20 lava flows are given in Table 1. The largest observed lava flows plot to the right of the gray line, marking $>20 \mathrm{~km}$ length, just beyond the range of the simulated values. These 5 flows were not considered when determining the parameter ranges for the lava flow simulations because lava flows of this length are effusion-rate limited, associated with very infrequent flank activity, and not found on the Shamiram Plateau. These results show that the volumes, thicknesses, and areal extents of nearly all observed flows fall within the ranges of the simulated values. 
Table 527 Mapped vents on the flanks of Aragats Volcano

\begin{tabular}{|c|c|}
\hline Easting & Northing \\
\hline 430920 & 4485826 \\
\hline 422295 & 4488512 \\
\hline 414366 & 4498480 \\
\hline 439898 & 4478024 \\
\hline 440441 & 4476970 \\
\hline 425896 & 4491003 \\
\hline 421407 & 4471589 \\
\hline 418534 & 4469462 \\
\hline 408119 & 4495051 \\
\hline 408990 & 4481638 \\
\hline 414068 & 4471495 \\
\hline 427253 & 4483296 \\
\hline 424558 & 4482259 \\
\hline 423136 & 4480327 \\
\hline 411159 & 4469329 \\
\hline 423682 & 4494414 \\
\hline 405800 & 4477396 \\
\hline 406683 & 4476948 \\
\hline 418530 & 4494870 \\
\hline 424111 & 4495248 \\
\hline 408363 & 4492635 \\
\hline 415964 & 4497175 \\
\hline 422344 & 4491454 \\
\hline 428042 & 4474090 \\
\hline 428225 & 4474806 \\
\hline 424775 & 4492714 \\
\hline 399806 & 4491891 \\
\hline
\end{tabular}

The location of 27 volcanic events used in the spatial density analysis of future volcanism on the flanks of Aragats volcano, units are UTM meters. These vent locations determine the closer-to-optimal bandwidth using the SAMSE bandwidth estimation method.

two-dimensional elliptical Gaussian kernel function to estimate spatial density. The SAMSE method, a modified asymptotic mean squared error approach, uses the distribution of known eruptive vents to optimally determine a smoothing bandwidth for the Gaussian kernel function. Potential vent locations $(\mathrm{N}=10000)$ are stochastically sampled from the resulting spatial density probability map. For each randomly sampled vent location, a lava flow inundation model is executed. Lava flow input parameters (volume and modal thickness) are determined from distributions fit to field observations of the low viscosity trachybasalt to trachydacite lava flows of the area. The areas and flow extents (a quantitative measure of lava flow length) of these simulated lava flows compare reasonably with those of mapped lava flows. This approach yields a conditional probability of lava flow inundation, given the opening of a new vent, and provides a map of vent locations leading to site inundation.
Table 6 Configuration file for simulation of lava flows from flank vents

\begin{tabular}{|c|c|}
\hline Parameter = Value & Explanation \\
\hline \multicolumn{2}{|l|}{ Inputs } \\
\hline DEM_SOUTH = 4441 & $N, S, E, W$ \\
\hline DEM_NORTH $=4482$ & boundaries \\
\hline DEM_WEST $=408$ & of the DEM \\
\hline \multicolumn{2}{|l|}{ DEM_EAST $=448$} \\
\hline DEM_SPACING $=0.1$ & DEM grid spacing $(\mathrm{km})$ \\
\hline DEM_FILE $=$ file & $\begin{array}{l}\text { (ASCIl format) rows of elevation values } \\
\text { (masl) }\end{array}$ \\
\hline MIN_RESIDUAL $=1$ & Map to observed flow thicknesses $(m)$ : \\
\hline MAX_RESIDUAL $=4$ & $\begin{array}{l}1=6,2=7,3=8,4=9 \\
\text { (lower value = lower lava viscosity) }\end{array}$ \\
\hline ERUPTED_LAVA = $1 \mathrm{e} 6$ & $\begin{array}{l}\text { Volume of lava distributed } \\
\text { per iteration or pulse }\left(\mathrm{m}^{3}\right)\end{array}$ \\
\hline MIN_TOTAL_LAVA $=1$ & Map to observed flow volumes $\left(\mathrm{km}^{3}\right)$ : \\
\hline MAX_TOTAL_LAVA $=3$ & $1=5 \times 10^{8} 2=5.3 \times 10^{8}, 3=8.7 \times 10^{8}$ \\
\hline FLOWS $=1$ & $\begin{array}{l}\text { Number of lava flows to simulate per } \\
\text { run }\end{array}$ \\
\hline RUNS = 1000 & Number of lava flow runs \\
\hline AOI_WEST $=426.0$ & Area of interest \\
\hline \multicolumn{2}{|l|}{ AOI_EAST $=428.2$} \\
\hline \multicolumn{2}{|l|}{ AOI_SOUTH $=4447.8$} \\
\hline \multicolumn{2}{|l|}{ AOI_NORTH $=4449.0$} \\
\hline SPATIAL_DENSITY_FILE $=$ file & $\begin{array}{l}X Y Z \text { format, grid of spatial density } \\
\text { values for the potential of volcanism } \\
\text { SPATIAL_DENSITY_SPACING=.1 }\end{array}$ \\
\hline $\begin{array}{l}\text { spacing of spatial density } \\
\text { grid }(\mathrm{km})\end{array}$ & \\
\hline
\end{tabular}

Configuration file for simulated lava flows from the flanks of Aragats volcano. The format of this ASCII file is parameter = value. The shown values reflect the range of values used for the lava flow simulation for hazard assessment from a flank eruption on Aragats.

Lava flow hazards exist at the ANPP site because potential eruptions on the Shamiram Plateau may produce lava flows that inundate the site. This Monte Carlo analysis has shown that, given the number of relatively small-volume lava flows occurring on the Shamiram Plateau, approximately $25 \%$ of all eruptions, resulting from the formation of a new vent, might also produce lava flows that inundate the ANPP site. Although very long and voluminous lava flows occur in the Aragats volcanic system, this analysis demonstrates that these types of flows do not present a credible hazard for the site, as the topography of the Shamiram Plateau would divert such potential flows away from the site area.

An integrated hazard assessment also depends on the estimation of the recurrence rate of effusive volcanism. Assuming a recurrence rate of effusive eruptions on the Shamiram Plateau of $4.1 \times 10^{-7} \mathrm{yr}^{-1}$ and $3.5 \times 10^{-6} \mathrm{yr}^{-1}$, based on currently available radiometric age 


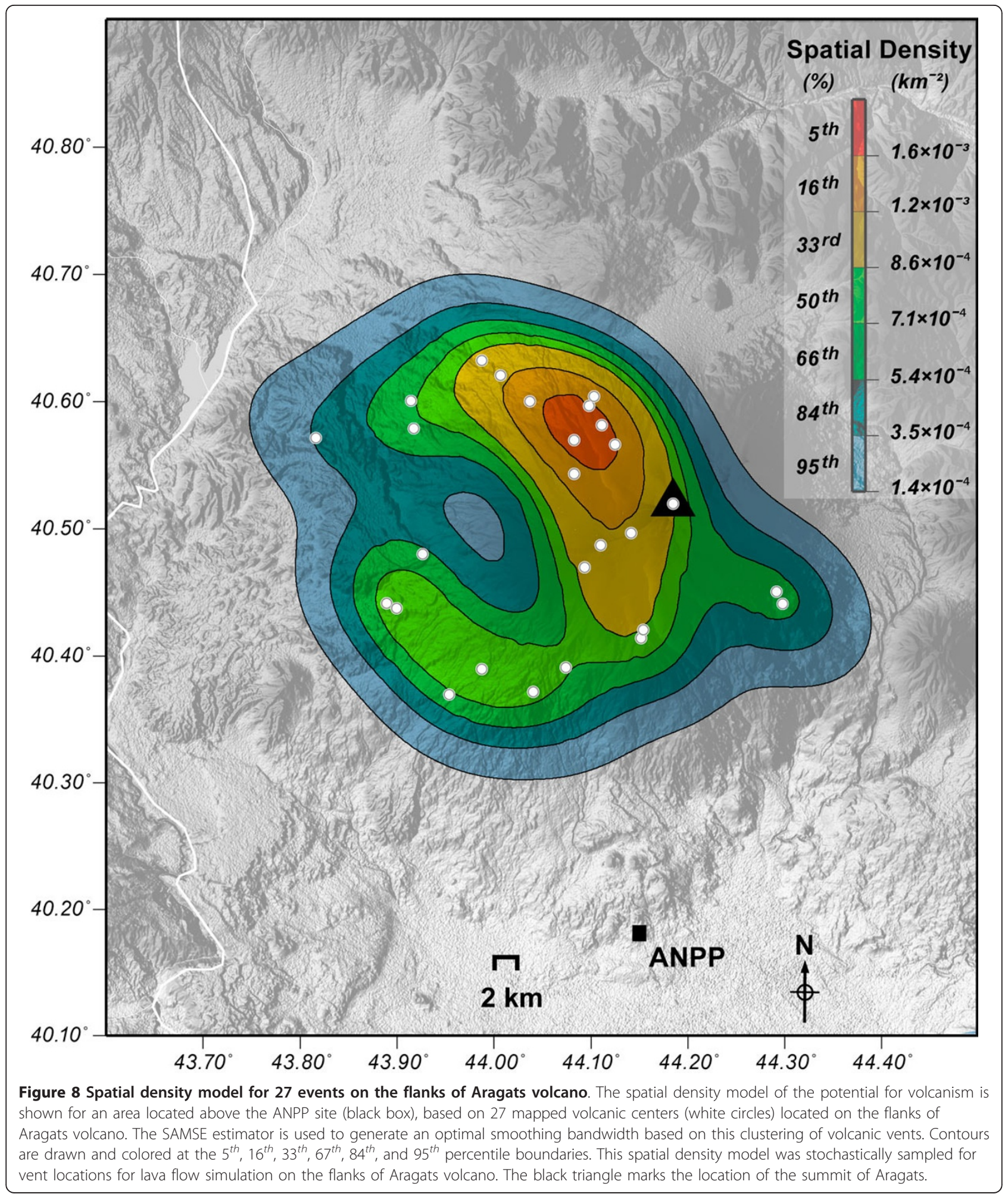

determinations (Chernyshev et al, 2002), the annual probability of site inundation by renewed effusive volcanism on the Shamiram Plateau is approximately $1.0 \times 10^{-7}$ to $8.8 \times 10^{-7}$.

\section{Methods}

Spatial density analysis

The lava flow hazard assessment begins with a spatial density analysis involving the locations of 18 volcanic 


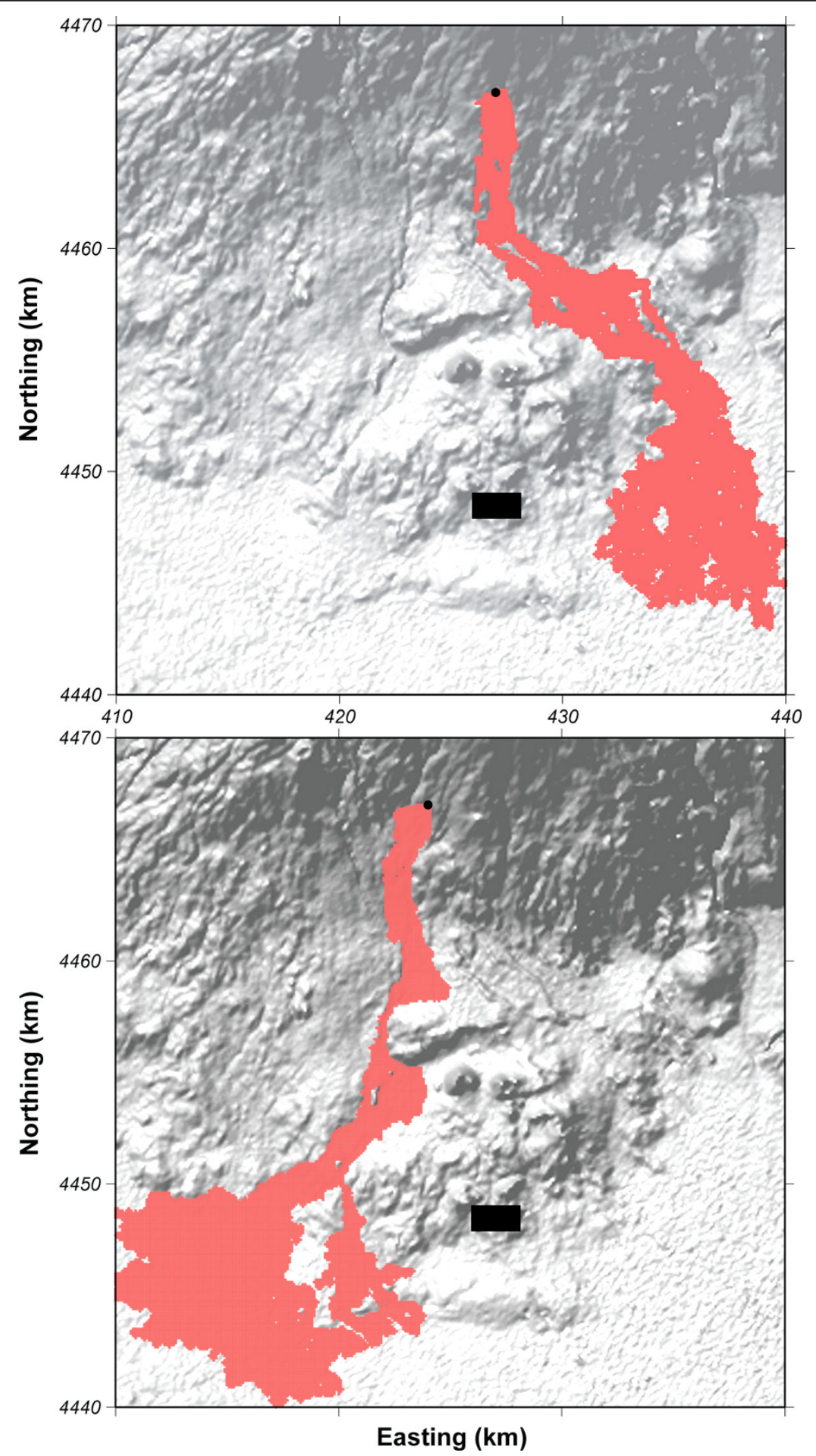

Figure 9 Two simulated large volume lava flows on the south flank of Aragats volcano. Simulated large-volume flows originating higher up the flanks of Aragats volcano divert around the topographic barrier presented by the Shamiram Plateau. These lava flows are simulated with a of volume $0.5 \mathrm{~km}^{3}$ and a thickness of $3 \mathrm{~m}$, similar to the Tirinkatar-1 and Ashtarak lava flows (Table 1)). The ANPP site is indicated by the black box. 
events located on the Shamiram plateau. This analysis will help determine the most likely locations of future volcanic events which will then become the source locations for possible lava flows. These events are listed in Table 2. Using these 18 events an optimal bandwidth is determined using the SAMSE method in the 'ks' package within the statistical program, ' $R$ '. The required ' $R$ ' commands are the following:

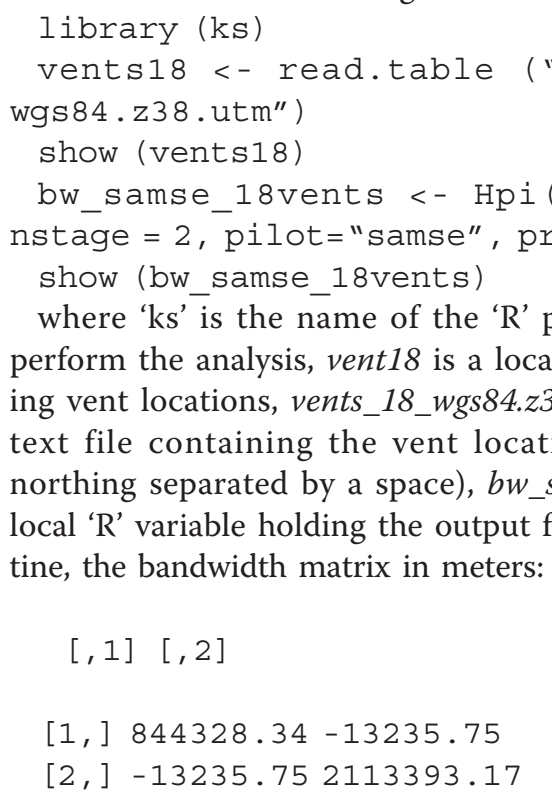
tine, the bandwidth matrix in meters:

$$
[, 1] \quad[, 2]
$$

$[1] 844328.34-$,

$[2]-,13235.752113393 .17$

where ' $k s$ ' is the name of the ' $R$ ' package needed to perform the analysis, vent 18 is a local ' $R$ ' variable holding vent locations, vents_18_wgs84.z38.utm is the input text file containing the vent locations (easting and northing separated by a space), $b w \_s a m s e \_18 v e n t s$ is a local ' $R$ ' variable holding the output from the 'Hpi' rou-

Spatial density analysis is accomplished using a PERL script (see Additional file 1). Parameters for the script are inserted directly at the top of the script as shown in the following code section:

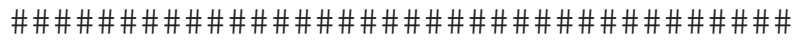

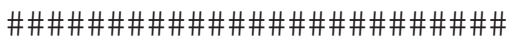

\# INPUT SECTION: These variables can be adjusted by the user

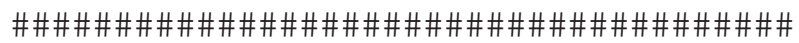
\#\#\#\#\#\#\#\#\#\#\#\#\#\#\#\#\#\#\#

\#\# This is the complete set of events:

\# events_zoom.wgs84.z38.utm: $\mathrm{N}=18$ $<425053 / 430618><4442102 / 4454652>$

my \$west $=420000$;

my \$east $=436000$;

my \$south $=4439000$;

my \$north $=4463000$;

my \$Grid_spacing $=100$;

\# The bandwidth matrix via SAMSE 2-stage pre-transformation 'sphering'

\# units = square meters, for 18 events near ANPP

$\#[, 1][, 2]$

\# $[1] 844328.34-$,

\#[2, ] -13235.752113393 .17$

\# units = square $\mathrm{kilometers}$

my $\$ H=p d l[$
$[.84432834,-.01323575]$,

$[-.01323575,2.11339317]$

];

\# The input file of event locations

my \$in = "events_zoom.wgs84.z38.utm" ;

\# The output file for the spatial intensity grid

my sout1 = "spatial_density_samse_events_zoom.wgs84.z38.utm.2";

where, \$north, \$south, \$east, \$west are the map boundaries in UTM meters, \$Grid_spacing is the map grid spacing, units in $\mathrm{km}, \$ H$ is the kernel bandwidth, units converted to $\mathrm{km}^{2}$, \$in is the name of the input file of volcanic event locations (ASCII format: easting northing), and \$out1 is the name of the output file of the spatial density grid (ASCII format: easting northing density).

$\$ \mathrm{H}$ is a matrix and its structure in the script is controlled by the PERL package 'pdl'. The 4 values for the matrix are derived from the output of the 'Hpi' routine (as noted above). To run the script from the command line type:

perl gausXY.pl

where 'gausXY.pl' is the name of the script. All parameters are inserted directly at the top of the script as indicated above.

A second PERL script drives the lava flow simulation (see Additional file 2 and Additional file 3). The inputs for this script are contained in a configuration file. To run the code from the command line type:

perl lava_flow.pl lavaflow.conf 0

where 'lava_flow.pl' is the name of the script, 'lavaflow.conf' is the name of the configuration file, and $O$ is the starting run number. Each run of the script simulates one complete lava flow simulation. The total number of simulated lava flows is set in the configuration file. The configuration file parameters are listed in Tables 4 and 6.

The PERL lava flow simulation script produces 3 output files:

lava_flow_stats.\# This file is a compilation of all simulated lava flows (where '\#' refers to the initial run number). This text file contains 6 columns:

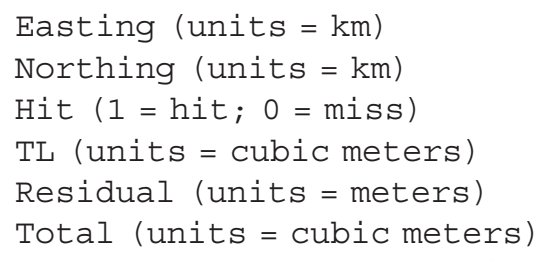

where Easting and Northing refer to the location of the erupting vent, Hit is either 1 or 0 , where 1 means that the lava flow penetrated the area of interest (i.e. the boundary of the site) and 0 indicates that it did not, $T L$ is the total volume of erupted lava, Residual refers to a flow's modal thickness, and Total is also the total 
volume erupted, but calculated in a different way. The total number of lava flow simulations are recorded.

flow.\#.utm This file records the grid location and thickness of lava in each inundated cell (where '\#' refers to an individual run number). This text file contains 3 columns: $X Y$ thickness, where $X Y$ refers to the inundated grid cell, and thickness refers to the thickness (m) of lava in that cell. This file is used to calculate the length and area of each simulated lava flow.

vents.utm This text file records the vent location of each lava flow simulation. The file contains two columns: Easting Northing.

\section{Additional material}

Additional file 1: PERL script that estimates spatial density. This code depends on inputs generated by the SAMSE bandwidth estimation routine from the ' $k s^{\prime}$ library package as part of the ' $R$ ' programming package. This PERL script is an ASCII (text) file that can be viewed with any text editor. It is run from the command line: perl.

Additional file 2: PERL script that simulates volume-limited lava flows from vents on and around the Shamiram Plateau. This lava flow script depends on the output spatial density grid file generated by the above mentioned spatial density script (additional file 1). It is an ASCIl file that can be viewed with any text editor. It is run from the command line: perl.

Additional file 3: Perl script that simulates effusion rate-limited lava flows from vents located on the flanks of Aragats. This lava flow script depends on the output spatial density grid file generated by the above mentioned spatial density script (additional file 1). It is an ASCII file that can be viewed with any text editor. It is run from the command line: perl.

\section{Acknowledgements}

The authors gratefully acknowledge the logistical and technical support of Staff at the Institute of Geological Sciences of Armenian National Academy of Sciences. Discussions with Arkadi Karakhanian regarding Armenian geology and field mapping greatly enhanced the authors' overall understanding of the geological setting of Armenia. Reviews of early results of this study by Britt Hill, Willy Aspinall, and Antonio Godoy, all representing the International Atomic Energy Agency, led to improvements in the methods presented here. This research was partially supported by a grant from the US National Science Foundation (DRL 0940839). Reviews by Britt Hill and Antonio Costa improved the manuscript.

\section{Author details}

'University of South Florida, 4202 E. Fowler Ave, Tampa, FL 33620, USA

${ }^{2}$ Institute of Geological Sciences of Armenian National Academy of Sciences, Yerevan, Armenia ${ }^{3}$ School of Earth and Environment, The University of Leeds, Leeds. LS2 9JT, UK

\section{Authors' contributions}

LC wrote spatial density and lava flow inundation computer codes and carried out lava flow simulations. CBC conceived of the study and participated in code development and analysis. LJC and CBC drafted the manuscript. KM and IS mapped lava flows on the Shamiram Plateau, developed the data set on lava flow parameters, and provided related geological and geochemical data. All authors read and approved the final manuscript.

\section{Competing interests}

The authors declare that they have no competing interests.
Received: 20 June 2011 Accepted: 25 January 2012

Published: 25 January 2012

\section{References}

1. Abrahamson N (2006) Seismic hazard assessment: Problems with current practice and future developments. First European Conference on Earthquake Engineering and Seismology, Geneva, Switzerland

2. Barca D, Crisci GM, Gregorio SD, Nicoletta F (1994) Cellular automata for simulating lava flows: A method and examples of the Etnean eruptions. Transport Theory and Statistical Physics 23:195-232

3. Bebbington MS, Cronin SJ (2010) Spatio-temporal hazard estimation in the Auckland volcanic field, New Zealand, with a new event-order model. Bulletin of Volcanology 73(1):55-72

4. Cappello A, Vicari A, Del Negro C (2011) Assessment and modeling of lava flow hazard on Mt. Etna volcano. Bollettino di Geofisica Teorica ed Applicata 52(2):10-20

5. Chernyshev IV, Lebedev VA, Arakelyants MM, Jrbashyan R, Ghukasyan Y (2002) Geochronology of the Aragats volcanic center, Armenia: Evidence from K-Ar dating. Doklady Earth Sciences 384(4):393-398. (in Russian)

6. Condit CD, Connor CB (1996) Recurrence rate of basaltic volcanism in volcanic fields: An example from the Springerville Volcanic Field, AZ, USA. Geological Society of America Bulletin 108:1225-1241

7. Connor $C B$, Connor $L J$ (2009) Estimating spatial density with kernel methods. In: Connor C, Chapman N, Connor L (ed) Volcanic and Tectonic Hazard Assessment for Nuclear Facilities. Cambridge University Press pp $331-343$

8. Connor CB, Hill BE (1995) Three nonhomogeneous Poisson models for the probability of basaltic volcanism: Application to the Yucca Mountain region. Journal of Geophysical Research 100:12 107-10 125

9. Connor CB, Stamatakos JA, Ferrill DA, Hill BE, Ofoegbu Gl, Conway FM, Sagar B, Trapp J (2000) Geologic factors controlling patterns of smallvolume basaltic volcanism: Application to a volcanic hazards assessment at Yucca Mountain, Nevada. Journal of Geophysical Research 105(1):417-432

10. Connor CB, Sparks RSJ, Díez M, Volentik ACM, Pearson SCP (2009) The nature of volcanism. In: Connor CB, Chapman NA, Connor $\mathrm{L}$ (ed) Volcanic and Tectonic Hazard Assessment for Nuclear Facilities. Cambridge University Press pp 74-115

11. Costa A, Macedonio G (2005) Computational modeling of lava flows: A review. Geological Society of America Special Papers 396:209-218

12. Del Negro C, Fortuna L, Vicari A (2005) Modelling lava flows by cellular nonlinear networks (CNN): preliminary results. Nonlinear Processes in Geophysics 12:505-513

13. Diggle P (1985) A kernel method for smoothing point process data. Applied Statistics 34:138-147

14. Dragoni M (1989) A dynamical model of lava flows cooling by radiation. Bulletin of Volcanology 51:88-95

15. Dragoni M, Tallarico A (1994) The effect of crystallization on the rheology and dynamics of lava flows. Journal of Volcanology and Geothermal Research 59:241-252

16. Duong $T$ (2007) Kernel density estimation and kernel discriminant analysis for multivariate data in R. Journal of Statistical Software 21(7):1-16

17. Duong T, Hazelton ML (2003) Plug-in bandwidth selectors for bivariate kernel density estimation. Journal of Nonparametric Statistics 15:17-30

18. Griffiths RW (2000) The dynamics of lava flows. Annual Review of Fluid Mechanics 32:477-518

19. Harris AJL, Rowland SK (2001) FLOWGO: a kinematic thermo-rheological model for lava flowing in a channel. Bulletin of Volcanology 63:20-44

20. Harris AJL, Rowland SK (2009) Controls on lava flow length. In: Thordarson T, Self S, Larsen G, Rowland SK, Höskuldsson A (ed) Studies in Volcanology, The Legacy of George Walker, Special Publications for IAVCEI No.2, The Geological Society, London, 33-51

21. Hill BE, Aspinall WP, Connor CB, Godoy AR, Komorowski JC, Nakada S (2009) Recommendations for assessing volcanic hazards at sites of nuclear installations. In: Connor CB, Chapman NA, Connor LJ (ed) Volcanic and Tectonic Hazard Assessment for Nuclear Facilities. Cambridge University Press pp 566-592

22. Hornik K (2009) The R FAQ. http://CRAN.R-project.org/doc/FAQ/R-FAQ.html. ISBN 3-900051-08-9

23. IAEA (2011) Volcanic hazards in site evaluation for nuclear power plants. Draft Safety Guide DS405. International Atomic Energy Agency, Vienna, Austria 
24. Jaquet $\mathrm{O}$, Connor $\mathrm{CB}$, Connor $\sqcup \mathrm{J}$ (2008) Probabilistic modeling for long-term assessment of volcanic hazards. Nuclear Technology 163(1):180-189

25. Jarvis A, Reuter HI, Nelson A, Guevara E (2008) Hole-filled seamless SRTM data. International Centre for Tropical Agriculture (CIAT), v4. available from http://srtm.csi.cgiar.org

26. Kilburn CJR, Lopes RMC (1988) The growth of aa lava fields on Mt. Etna, Sicily. Journal of Geophysical Research 93:14,759-14,722

27. Kilburn CJR, Luongo G (1993) Active Lavas: Monitoring and Modelling. UCL Press, London, UK

28. Kiyosugi K, Connor CB, Zhao D, Connor L, Tanaka K (2010) Relationships between temporal-spatial distribution of monogenetic volcanoes, crustal structure, and mantle velocity anomalies: An example from the Abu monogenetic volcano group, southwest Japan. Bulletin of Volcanology 71. doi:10.1007/s00,445-009-0316-4

29. Le Bas M, Le Maitre RW, Woolley AR (1986) The construction of the total Alkali-Silica chemical classification of the volcanic rocks. Mineralogy and Petrology 46(1):1-22

30. Luhr J, Simkin T (1993) Paricutin: the Volcano Born in a Mexican Cornfield. Geocsience Press, Inc, Phoenix, AZ

31. Malin MC (1980) Lengths of Hawaiian lava flows. Geology 8:306-308

32. Martin AJ, Umeda K, Connor CB, Weller JN, Zhao D, Takahashi M (2004) Modeling long-term volcanic hazards through Bayesian inference: example from the Tohoku volcanic arc, Japan. Journal of Geophysical Research 109(B10208). doi:10.1029/2004JB003,201

33. Miyamoto N, Sasaki S (1997) Simulating lava flows by an improved cellular automata method. Computers and Geosciences 23:283-292

34. Molina S, Lindholm CD, Bungum H (2001) Probabilistic seismic hazard analysis: Zoning free versus zoning methodology. Bollettino di Geofisica Teorica et Applicata 42(1-2):19-39

35. Pinkerton H, Wilson L (1994) Factors controlling the lengths of channel-fed lava flows. Bulletin of Volcanology 56:108-120

36. Rowland SK, Gabriel H, Harris AJL (2005) Lengths and hazards of channelfed lava flows on Mauna Loa (Hawaii), determined from thermal and downslope modeling with FLOWGO. Bulletin of Volcanology 67:634-647

37. Silverman B (1986) Density Estimation for Statistics and Data Analysis. No. 26 in Monographs on Statistics and Applied Probability, Chapman and Hall

38. Silverman BW (1978) Choosing the window width when estimating a density. Biometrika 65:1-11

39. Stasiuk MV, Jaupart C (1997) Lava flow shapes and dimensions as reflections of magma system conditions. Journal of Volcanology and Geothermal Research 78(1-2):31-50

40. Stock C, Smith EGC (2002) Comparison of seismicity models generated by different kernel estimations. Bulletin of the Seismological Society of America 92:913-922

41. Thordarson T, Self S (1993) The Laki (Skaftar fires) and Grimsvotn eruptions in 1783-85. Bulletin of Volcanology 55:233-263

42. Volentik ACM, Connor CB, Connor $\amalg$, Bonadonna C (2009) Aspects of volcanic hazard assessment for the Bataan nuclear power plant, Luzon Peninsula, Philippines. In: Connor CB, Chapman NA, Connor L (ed) Volcanic and Tectonic Hazard Assessment for Nuclear Facilities. Cambridge University Press pp 229-256

43. Wadge G, Young PAV, McKendrick IJ (1994) Mapping lava flow hazards using computer simulation. Journal of Geophysical Research 99:489-504

44. Walker GPL (1973) Lengths of lava flows. Philosophical Transactions of the Royal Society, London 274:107-118

45. Wand MP, Jones MC (1995) Kernel Smoothing. No. 60 in Monographs on Statistics and Applied Probability, Chapman and Hall

46. Ward SN (1994) A multidisciplinary approach to seismic hazard in southern California. Bulletin of the Seismological Society of America 84:1293-1309

47. Woo G (1996) Kernel estimation methods for seismic hazard area source modelling. Bulletin of the Seismological Society of America 88:353-362

doi:10.1186/2191-5040-1-3

Cite this article as: Connor et al:: Probabilistic approach to modeling lava flow inundation: a lava flow hazard assessment for a nuclear facility in Armenia. Journal of Applied Volcanology 2012 1:3. 